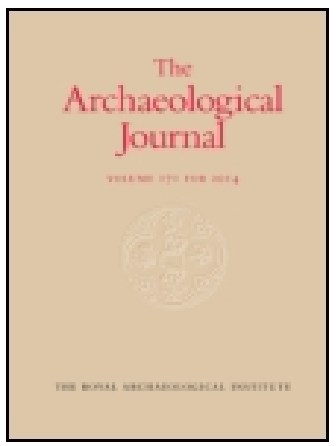

Archaeological Journal

\title{
Notice of Remains of The Anglo-Saxon Period, Discovered at Little Wilbrailam, Cambridgeshire
}

\author{
Mr. Deck F.G.S.
}

To cite this article: Mr. Deck F.G.S. (1851) Notice of Remains of The Anglo-Saxon Period, Discovered at Little Wilbrailam, Cambridgeshire, Archaeological Journal, 8:1, 172-178, DOI: 10.1080/00665983.1851.10850821

To link to this article: http://dx.doi.org/10.1080/00665983.1851.10850821

Published online: 10 Jul 2014.

Submit your article to this journal $\square$

Џ Article views: 2

Q View related articles $\sqsubset$ 
NOTICE OF REMAINS OF THE ANGLO-SAXON PERIOD, DISCOVERED AT LITTLE WILBRAIIAM, CAMBRIDGESHIRE. COMMUNICATED BY MR. DECK, F.G.S.

In the line of the direct Roman road forming part of the Ickling Street-way from Royston to Caistor, and passing through the well-known Devil's Dyke on Newmarket Heath, is a considerable elevation formed by the clunch or lower chalk marl. This is in the parish of Little Wilbraham, about six miles from Cambridge, and is well known to the villagers by the Anglo-Roman name of "Streetway-hill." - The whole line abounds with tumuli, as may be observed on the map of the Ordnance Survey, marking the places of sepulture of the honoured dead of the warlike Iceni, the Romans and the Anglo-Saxons, as appears by the explorations made ; and at various periods the plough and the spade have turned up numerous interesting relics, showing the successive occupation of the spot by these different races.

About four years since several remarkable fibulæ, armillæ, amulets, coins, and beads, some of which were exhibited at the Oxford Meeting of the Institute, were found, and successive operations have brought to light many other relics and numerous human remains. Early in the last year (1850), the summit of the hill was lowered, and, in effecting this, an escarpment of the chalk marl cut through exhibited the difference of soil that had upon former occasions suggested the probability of a deposit, and which, in many instances, proved to be correct. Upon carefully removing this soil, which was easily effected by the section made in sloping down the cutting, there was found a rectangular grave, $6 \mathrm{ft} .4 \mathrm{in}$. long, by $2 \mathrm{ft}$. $8 \mathrm{in}$. wide, in which was deposited, with much apparent care, a human skeleton of great stature. From the comparative measurement of the femur and tibia, the tenant of this tomb must have exceeded by some inches the height of six feet. The body was laid with the face downwards, and with the feet towards the east.

Partly upon the occipital portion of the cranium, and the cervicular vertebra, was placed a curious and apparently unique object, the form of which is shown by the accompanying representation. This, I am disposed to regard as a headpiece or kind of crown, intended as a mark of honour 


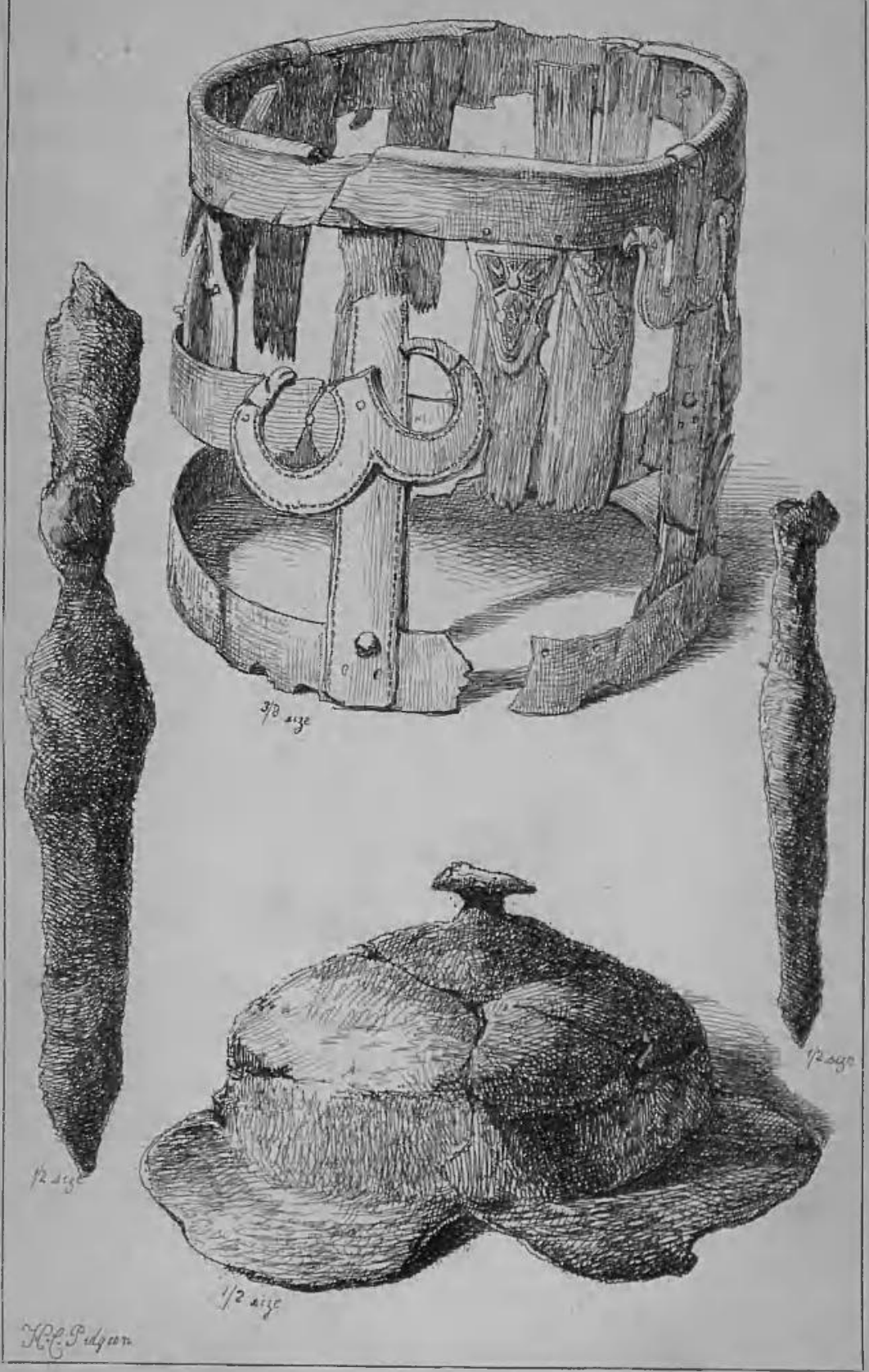


to the illustrious dead. It is composed of a frame-work of wood, surrounded and kept together by three circlets of fine bronze metal, $1 \frac{1}{4} \mathrm{in}$. wide, the lower rim skilfully turned up at the edge and well finished. These are held in their places by four uprights, of the same metal, placed at equal distances, ornamented at intervals by recurved horn-shaped pieces of

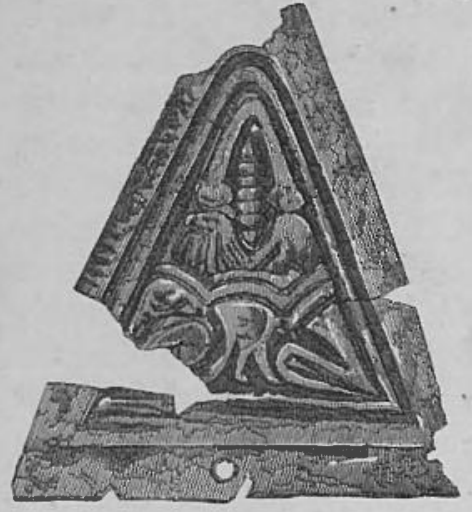

'Traugular Ornament of thin bronze plate. Orig. size. metal, with curious grotesque terminations, and rivetted in a workman-like manner to the upright parts. The lower rim was surrounded by stamped metal of thin bronze, $2 \frac{1}{9} \mathrm{in}$. high, terminating in a series of decorative triangular plates of thin bronze, as seen in the plate; the whole forming an ellipsis of $8 \frac{3}{4} \mathrm{in}$. by 7 , and 8 in. high. Under the breast was found a spear-head of iron, not differing in form from those of the period to which these remains have been attributed; and on the right side the small iron knife or dagger (see Plate) often found to be characteristic of this mode of sepulture. Upon the tiliza lay an iron umbo, or boss, the only remnant of the shield. This, with the peculiar markings of the bronze ornaments, led to the conclusion that this interesting relic was of early Saxon date.

The cranium, of which the whole portion, from the occipital to the frontal bone, is entire, presents a remarkable conformation, and has excited the attention of the members of the medical profession to whom it has been submitted. The measurement from each extremity is largely out of proportion, forming an elongated oval of extraordinary dimensions; this curious relic of mortality will, with three others of similar malformation, which have been found in Cambridgeshire within the last ten years, form a subject of interesting investigation. They have been submitted to Dr. Thurnam, who is about to favour us with the result of his discriminating observations upon these and other distortions of the human cranium.

That this bronze ornament was intender as the insignia of honour-as a crown to the illustrious dead, I have no doubt; although this assertion is in opposition to the ideas vor. viII. 
of several archaeologists, for whose opinions I entertain high respect, and who consider it to have been a vessel in the form of a bucket or situla, similar to one which was found at Hexham, and is now deposited in the British Museum, ${ }^{1}$ or to that found at Northfleet, in $1847 .^{2}$ My objections to this opinion are, that in this instance this object was deposited on a portion of the body where it would obviously be placed as a mark of honour. As a situla, the position in which it was found was an inverted one, whereas, if intended as a crown, it was in its proper direction. If it had served as a vessel, such as has been supposed, it must have had a bottom; but the most accurate search failed in discovering the slightest trace of such an adjunct, although the decayed portions of the upright staves were collected; and, lastly, it is not probable that it would have been deposited empty, as those in the instances already cited were filled with relics,- that found at Hexham containing some thousands of Anglo-Saxon coins, and it may be presumed that, had this contained any object, some vestiges of its contents must have been discovered.

It is probable that a tumulus once crowned the summit of this sepulchral deposit, although no such tradition is handed down; but, as it is a highly cultivated part of the country, the successive operations of the husbandman hare no doubt reduced it to its present level. The site is one worthy of those suitably selected for the tomb of a warrior -its elevation commanding a complete panoramic view of the whole surrounding country, forming an important military station either for attack or defence; the traces of the outworks, with the warlike relics constantly found, determine it to have been a position of considerable importance, as well as the scene of many successive military operations.

These relics will be deposited in the British Museum-in the "British Room," recently completed-where they may supply an important link in the chain of historical vestiges about to be chronologically arranged in the new department, so desirably appropriated to the exclusive illustration of British antiquities.

In April of the present year (1851), some labourers employed in digging chalk on Streetway Hill, within a few feet of the spot where the above-noticed discovery took place, came upon an extensive deposit of human remains,

1 See Archæologia, vol. xxv., p. 279.

2 Journal of the Archæol. Assoc, vol. iii., p. 235. 
numerous iron spear-heads, several fine iron bosses, perfect even to the bronze rivets which fastened them to the shield; all of similar type to those found with the skeleton and crown ; some of these are in my possession, and form additional proof of the occupation and importance of this position during the Anglo-Saxon period.

The ridge of chalk marl in which all these relics have been discovered is being gradually carted away by the occupier of the neighbouring soil, as he requires it for agricultural purposes; above twenty yards are as yet undisturbed, and as these probably contain many equally interesting remains, it is much to be desired that an excavation should take place, under the superintendence of the Cambridge Antiquarian Society, or some other Archaeological authority, ere the ruthless spade of the labourer entirely removes the last portion of this remarkable ridge.

I. D.

\section{Note Relating to the REMaINS FoUNd at LitTle WilbrahaM.}

IT is highly gratifying to be enabled to assure our readers, that the remarkable relics of antiquity, described in the foregoing memoir, have been presented by $\mathrm{Mr}$. Deck to the Collection, long desired, and now in course of arrangement in the "British Room." His Grace, the DUKE of Northumberland, had given a noble precedent, by the donation of an unique assemblage of antiquities discovered upon his estates at Stanwick, and deposited by him at the British Museum, through the intervention of the Archaeological Institute, in pursuance of his purpose to encourage the formation of a National Series. All who feel an interest in such an object will give their heartiest acknowledgment to the antiquary, who, like Mr. Deck, is amongst the very foremost to follow the generous example to which we have alluded.

The curious question of the true appropriation of the object, by some designated as a kind of situla, occasionally discovered with interments of the Anglo-Saxon age, may be determined by future researches. Mr. Deck bas submitted to our readers the results of his consideration of the subject; and, although his views may not meet with general acceptance, it must be remembered that they received confirmation from actual inspection of the condition and minute details, connected with these relies, in situ-an advantage which all will appreciate.

A few notices of analogous discoveries may serve to throw light upon this enquiry. The curious vessel of bronze, to which Mr. Deck has alluded, the receptacle in which a hoard of stycas of the ninth century was brought to light in "Campey Hill," at Hexham, although varied in form from the object found at Little Wilbraham, and some others of a similar class, may perhaps properly be compared with them, and especially in the characteristic Vandyked decoration around the rim. (See Archaeologia, vol. xxv., pl. 33.) This vessel, however, was of different form, being considerably wider at the 
base than at the upper margin. The bronze hoops and handle of a situla of similar form were found in a Saxon tumulus at Bourne Park, Kent, by Lord Londesborough, with an umbo, bridle-bit of iron, and a flat bowl of gilt metal. (Archaeol. Journal, vol. i., p. 255.) In other discoveries assigned to the Anglo-Saxon age, a situla has been noticed, found with the iron umbo, axe-head, and other relics usually found in graves of that period. One of the best examples probably, although of small size, is that discovered in the burial place at Ash, near the high road thence to Canterbury, in 1771. It is represented in the Appendix to Boys" " History of Sandwich," (p. 868,) and in Douglas' Nenia, (pl. 12, p. 51). It is described as a vessel in the shape of a pail, 8 inches in diam., and $7 \frac{1}{2}$ in height. It had, as it is stated, a handle like a modern pail, and was formed of wood, either of the ash or plane tree, strengthened by upright plates, and three flat hoops ; to the upper hoop was attached a row of triangular plates of thin bronze, (their points downwards) with inıpressed markings, forming a Vandyked ornament around the pail. It must be stated, that no record was made of any bottom having been found, but it was supposed that it had been of wood, and had perished. A shallow basin and a patera of bronze, a touchstone, portions of a pair of scales, and some Roman coins, which had served as weights, were found with this deposit. The iron axe may appear to indicate that it was not the sepulture of a female. There were found also a stone celt and a crystal ball, with other objects.

In the neighbourhood of Marlborough a remarkable situla, or drum-shaped vessel, employed for a sepulchral purpose, was found, as recorded by the late Sir Richard Colt Hoare ("Ancient Wilts," vol. ii., p. 34, pl. vi.). It was formed of substantial oak, plated with thin brass, ribbed with iron hoops, had two iron handles, one at each side, and a hollow bar of iron placed across the mouth, and affixed to two pieces projecting above the upper rim of the vessel. The surface was curiously ornamented with grotesque human heads, animals, \&c., embossed in the metal plating. The dimensions of this curious vessel were, height 21 inches, diam. 24 inches. The sides, like those of the hooped wooden vessel found in Cambridgeshire, were upright. It contained a deposit of burned human bones.

Amongst some highly interesting remains of the Anglo-Saxon period, found at Northflect, Kent, and described by Mr. Roach Smith in the Journal of the British Archaeological Association (vol. iii., p. 236), was found the remains of a wooden pail, with bronze hoops and a bi-cornute ornament of the same metal, riveted on, closely similar to those on the upright bands of the object from Little Wilbraham. With this deposit were also found an iron umbo, terminating in a flat button, and an iron spear, precisely similar to those found in Cambridgeshire, a spear-head of longer proportion, a long iron ferrule for the shaft of the spear, an iron sword, and pottery. The account of this remarkable discovery has been appended by Mr. Alfred Dunkin to his "Memoranda of Springhead" (p. 150).

In a tumulus on Roundway Down, near Devizes, a collection of highly curious ornaments was brought to light about 1843 , on the property of Mr. E. Colston. The corpse lay north and south, in a rooden chest, bound with iron. Near the neck were found several ornaments, composing a necklace ; garnets set in gold, in fashion like the Roman bulla, seemed to have been arranged alternately with barrel-shaped beads of gold wire. There were also two gold pins, set with gamets, united by a chain, in the centre of which was a circular ornament, bearing a cruciform device engraved upon its setting. At the feet lay the remains of a bronze-bound 
object, apparently identical with those found at Ash and at Northfleet. It fell to pieces on admission of the air, and the remains consisted of curved plates of thin bronze, which doubtless hnd formed the hoops, and about twenty triangular plates, which appeared to have been attached by rivets over one of the hoops, and had probably formed a Vandyked ornament, as noticed in the other examples. These thin plates were simply ornamented with rows of dots, hammered up in the metal. Some minor objects of bronze were also noticed, seemingly parts of a kind of fastening or padlock; and remains of two earthen cups. In this discovery, it was conjectured that these remains had formed part of a helmet; but, whilst the thin fabric of the metal plate was wholly unsuited to such a purpose, the discovery of so rich a necklace and other ornaments with the corpse, justify the conclusion that the remains were those of a female; for whose choice appliances and ornaments this bronze-bound capsa had probably served as a receptacle.

Mr. J. Y. A renman, who laid these interesting relics before the Society of Antiquaries, considered the interment to be of the VI. or VII. century. ${ }^{3}$

To Mr. Franks we are indebted for pointing out an interesting fragment lately found by him amongst the disjecta membra of British antiquity, the arrangement of which is now in progress at the British Museum. It is a thin ormamental plate of bronze, of triangular form, found between Sandgate and Dover, doubtless a portion of the metal mountings of an object similar to those already described.

As these ancient relics of the Anglo-Saxon age have conjecturally been regarded as connected with some kind of helmet, it may not be irrelevant to advert to the remains of certain Saxon objects of a different class, hooped or bound with a framework of thin metal, which do appear to have composed some lind of head-piece, during that period. Of this description appears to have been the curious frame of bronze found on the skull in an interment discovered on Leckhampton Hill, near Clieltenham. (Archaeol. Journ., vol. i., p. 387 ; figured in vol. iii., p. 352.) Another, found at Souldern, Oxfordshire, on the Portway, found, as described by Sir Henry Dryden, about the head of the deceased. Fragments of leather were to be seen between the thin brass plates. ${ }^{4}$ Another remarkable example is described by $\mathrm{Mr}$.

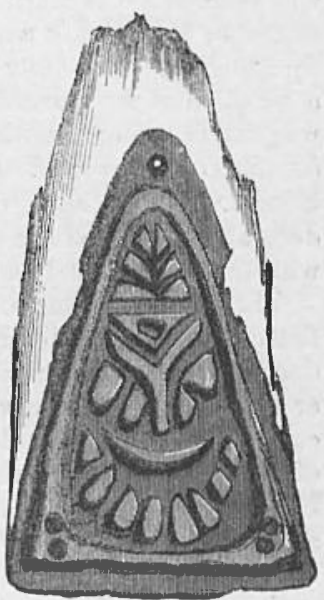

Plate of bronze in I3rit. Mus. Urig. eize. Bateman, found in a Saxon tumulus in Derbyshire. (Journal of Archacol. Assoc., vol. iv., p. 278.) This head-piece was regarded by the late Sir Samuel Meyrick as the British " Penfestyn."

It is highly interesting to compare with these discoveries in our own country, the assemblage of relics of the same age found in 1740 , on the banks of the Meuse, near Verdun. They are represented in the "Museum Schœpflinum," (Argentorati, 1773, tab. xvi.) Oberlin, who describes this deposit, conceived it to have been the sepulchre of some great prince, possibly King Theodebert, or Theodebald, in the sixth century. There werc found a shallow vessel of bronze, an umbo and an axe-head of iron

${ }^{3}$ See a Notice in the Minutes of the Society of Antiquaries, vol.i., p. 12. A similar necklace, pins, \& c., were found by
Mr. Bateman, near Buxton. Vestiges, p. 94. 4 Antiquities of Steeple Aston, by William Wing, p. 73. 
(similar to those disinterred at Ash). The umbo had been attached to the shield by silver-headed nails. There was part of an iron sword-blade, a bronze spear-head, and a long iron ferrule, or the head of a framea, possibly such as was found at Springhead. The most curious feature of this discovery was a richly ornamented broad hoop of gilt bronze, with a handle, moveable precisely like the handle of a pail, and attached to the hoop by singular recurved ornaments, in some degree analogous to the cornute plates upon the Cambridgeshire relic. This was regarded by Oberlin as the metal mounting of the head-piece, or crown; and he compared it with those of Tiberius and Maurice, on their coins. ${ }^{5}$ Traces of hard leather were visible between the lamine of bronze forming this supposed crown, naturally suggestive of the notion that it had been a pileum, or leathern head-gear ; but, whilst the adjustment of the handle with a transverse movement like that of a pail seems wholly adverse to the conjecture that it had been the decoration of a cap or crown, the appearance of the leather may induce the supposition that the object was not a crown, but a leathern, bronze-bound crumena, in which some precious possessions of the deceased were deposited with his ashes in the grave. The use of leather in constructing vessels such as this may have been, or in closing either of their ends, will sufficiently account for the absence of any indications of a bottom, as stated in Mr. Deck's notice, and the recital of the discoveries at Ash, given by Douglas. We may feel less hesitation in presuming to controvert the conclusion of the learned Oberlin that the studded hoop found near Verdun was the frame of a crown, since he was equally satisfied that the iron $u m b o$ (of the ordinary and undeniable fashion of our Saxon period ${ }^{6}$ ) was an helmet. At the same time, some analogy must be recognised between this decorated hoop and the examples of the supposed leathern Penfestyn, bound with brass, previously described.

The form of a supposed repository for objects of value, which appears in these examples, is closely analogous to that of the capsa of a remoter age, a deep, circular, wooden box, in which writings or other valuables were preserved or transported, and to which straps were attached. In the capsa under consideration, the handle was of a more rigid fashion. The bronze scrinium of similar form, but minor dimension, found in a tumulus at Sibbertswold, Kent, deserves examination. It contained thread, and was probably an appliance of female use. ${ }^{7}$

The antiquities of the Anglo-Saxon Period are highly interesting and varied in their form and decoration. The formation of a classified series in the National Repository must tend to dispel the obscurity which, in many instances, still exists regarding their use or origin. In a previous page reference has been made to certain objects represented on several Gaulish sepulchral sculptures, a sort of little bucket, or coffer, with a handle like a situla, carried in the hand. ${ }^{8}$ Some resemblance appears to exist between these and the brass-bound receptacles found in Saxon interments. It is, moreover, remarkable that the examples in question are exclusively on tablets of a sepulchral nature. With these may be compared an interesting group of the parents with their two children, who carry objects of the like form as those on the Gaulish tombs in Lorraine. This sculpture, attributed to the Roman age, was found in Bavaria. ${ }^{9}$

A. W.

5 See Ducange, in fam. Byzant.

- Admirably shown by Douglas, pl. 1, an example with the terminal button and studs silvered.
- Douglas, Nenia, pl. xviii.

See Note 1, p. 89, ante.

9 Wagener, Handbuch, fig. 1014. 